\title{
Sosyal Bilişsel Kariyer Kuramı Açısından STEM Kariyer İlgisine Cinsiyetin Etkisi
}

\author{
DOI: $10.26466 /$ opus.603981
}

$*$

\author{
Ayșegül Ergün * \\ * Dr. Öğr. Üyesi Manisa Celal Bayar Üniversitesi, Eğitim Fakültesi, Demirci / Manisa \\ E-Posta: ergunaysegul@gmail.com \\ ORCID: 0000-0002-1481-4019 \\ $\ddot{O} z$
}

$B$ u araştırmanın amacı, sosyal bilişsel kariyer kuramı açısından ortaokul öğrencilerinin STEM kariyer ilgilerine cinsiyetin etkisinin belirlenmesidir. Araştırmanın örneklemi, Ege bölgesindeki bir ilçede bulunan devlet ortaokulunda öğrenim gören 400 öğrenciden (218 kız, 182 erkek) oluşmaktadır. Genel tarama modelinin kullanıldığı araştırmada veriler, STEM kariyer ilgi anketiyle toplanmıştır. Araştırma sonucunda erkek öğrencilerin STEM kariyer öz yeterliklerinin ve ilgilerinin, kız öğrencilere göre daha olumlu olduğu belirlenmiştir. Öz yeterlik düzeyinin teknoloji ve mühendislik alanlarnnda erkek öğrenciler lehine, matematik alanında ise kız öğrenciler lehine farklılık gösterdiği bulunmuştur. Kişisel amaç ve sonuç beklentilerinin, fen ve matematik alanlarında kız öğrenciler lehine, teknoloji ve mühendislik alanlarında ise erkek öğrenciler lehine anlaml farklllık gösterdiği belirlenmiştir. Kız öğrencilerin teknoloji ve mühendislik alanlarmdaki öz yeterlik, kişisel amaç ve sonuç beklentilerinin erkeklere göre daha düşük olduğu, bu nedenle kız öğrencilerin STEM kariyer ilgilerinin de erkeklere göre daha olumsuz olduğu sonucuna varılmıştır. Elde edilen bulgular ışı̆̆ında, kız öğrencilerin mühendislik ve teknoloji alanlarındaki kariyer ilgilerinin olumlu yönde gelişimi için ortaokulun ilk yıllarından itibaren yeterli mesleki rehberlik yapılması önerilmiştir.

Anahtar Kelimeler: STEM kariyer ilgisi, ortaokul öğrencileri, sosyal bilişsel kariyer kuramı 


\title{
The Impact of Gender on STEM Career Interest in Terms of the Social Cognitive Career Theory
}

\begin{abstract}
The purpose of this study was to determine the effect of gender on middle-school students' STEM career interest in terms of the social cognitive career theory. The sample of the study was consisted of 400 students (218 female and 182 male students) who are receiving education at public middle-school in a district in the Aegean region in Turkey. Data of the study in which general survey model has been used have been collected through the STEM career interest survey. As a result of the study, it has been seen that the male students' STEM career self-efficacy and interest is more positive compared to the female students. Self-efficacy level was found in the favor of the male students in the areas of technology and engineering and in the favor of the female students in the area of mathematics. It was seen that personal goals and expectations related to results displayed differences in the favor of the female students in the areas of science and mathematics and in the favor of the male students in the areas of technology and engineering. It has been concluded that the self-efficacy, personal goals and expectations related to results of the female students in the areas of technology and engineering are lower compared to the male students and thus, female students' STEM career interest is more negative compared to the male students. In the light of the findings obtained in the study, it is suggested to provide sufficient occupational guidance starting from the middle-school years for the positive development of the female students' career interests related to technology and engineering.
\end{abstract}

Keywords: STEM career interest, middle-school students, social cognitive career theory 


\section{Giriş}

21. yüzyılda artan küreselleşme ile birlikte bilgi ve iletişim teknolojilerinde de çok hızlı gelişmeler yaşanmaktadır. Bu gelişmeler ülke ekonomilerini de etkilemiş ve ekonominin daha çok bilgiye dayalı olması sonucunu doğurmuştur. Ekonomik anlamda küresel rekabet gücüne sahip olmak isteyen ülkelerin, yeni teknolojiler geliştirebilecek ve yenilikçi ürünler üretebilecek bireylere olan ihtiyacı da artmıştır. Bu bağlamda ülkelerin 21. yüzyılda dünyaya liderlik edebilmek için öncelikli hedefi fen, teknoloji, mühendislik ve matematik (STEM) alanlarında kariyer sahibi bireyler yetiştirmek olmuştur (Milli Eğitim Bakanlığ1 [MEB], 2016). Ülkelerin STEM işgücü ihtiyacını karşılamak için eğitim politikalarında STEM entegrasyonuna yönelik girişimlerde bulundukları görülmektedir.

Türkiye'de öğretim programlarına STEM entegrasyonu için ilk adım, 2005 yılında "Fen Bilgisi" dersinin isminin 'Fen ve Teknoloji' olarak değiştirilmesi ile atılmıştır (MEB, 2006). Bu adımın ardından 2016 yılında yayınlanan STEM eğitimi raporunda, öğretim programlarının STEM'e göre güncellenmesi ve okullarda STEM eğitimi ortamlarının oluşturulması için gerekli ders materyallerinin sağlanması gibi konular vurgulanmıştır (MEB, 2016). 2017 yılında Fen Bilimleri Dersi Öğretim Programı'nda güncelleme yapılarak taslak bir program hazırlanmıştır. Programın bilgi boyutuna, 4. sinıftan 8. sinıfa kadar 'Fen ve Mühendislik Uygulamaları' ünitesi, beceri boyutuna ise 'Mühendislik ve Tasarım Becerileri' eklenmiştir (MEB, 2017). 2018 yılında yayınlanan programda ise taslak programdaki 'Fen ve Mühendislik Uygulamaları' ünitesi yerine, tüm ünitelerde 'Fen, Mühendislik ve Girişimcilik Uygulamaları' na yer verilmiştir. Bu uygulamalar kapsamında, öğrencilerin ünitelerde ele alınan konulara ilişkin günlük hayattan bir problemi tanımlamaları, problemin çözümüne yönelik çözüm yollarından uygun olanı seçmeleri, seçtikleri çözüme yönelik bir ürün ortaya koymaları ve ürünü sunmaları beklenmektedir (MEB, 2018).

Birçok Avrupa ülkesinde STEM eğitimine yönelik ilginin artmasına rağmen üniversite eğitiminde fizik bilimleri, mühendislik ve matematik alanlarını seçen öğrenci sayılarında düşüş yaşanmaktadır (Osborne ve Dillon, 2008). Benzer olarak Türkiye'de 2000 yılından 2014 yılına kadar 
sayısal alanlarda üniversitelere yerleşen ilk bin öğrencinin STEM alanlarına yerleşme oranlarında düşüş yaşandığı belirtilmektedir (Akgündüz, 2016). 2015 yılında OECD ülkelerinde yükseköğretimde STEM alanlarını seçenlerin sayılarına bakıldığında da, Türkiye'nin OECD ortalamasının altında kaldığı belirlenmiştir (Organisation for Economic Cooperation and Development [OECD], 2017). Türk Sanayicileri ve İşadamları Derneği'nin (TÜSİAD) (2017) raporuna göre, 2016-2023 döneminde STEM istihdam gereksiniminin yaklaşı \%31'inin karşılanamayacağı öngörülmektedir. Bu bağlamda öğrencilerin STEM kariyerlerine yönelik ilgilerinin erken yaşlarda belirlenmesinin ve gelişimine yönelik girişimlerde bulunulmasının, ülkelerin STEM işgücü ihtiyacının karşılanması açısından önem taşıdığ 1 ifade edilebilir.

\section{STEM Kariyer İlgisi ve Cinsiyet}

STEM kariyer ilgisi ile cinsiyet arasındaki ilişkinin belirlendiği araştırmaların sonuçları, genel olarak kadınların STEM alanlarına yönelik kariyer ilgilerinin, erkeklere göre daha düşük düzeyde olduğunu göstermektedir (Christensen ve Knezek, 2017; Knezek, Christensen ve Tyler-Wood, 2011; Sadler, Sonnert, Hazari ve Tai, 2012; Su, Rounds ve Armstrong, 2009; Unfried, Faber ve Wiebe, 2014). Son yıllarda ise farklı araştırma sonuçları ile karşılaşılmıştır. Örneğin bir araştırmada STEM kariyer ilgisinin cinsiyete göre farklılık göstermediği (Yerdelen, Kahraman ve Taş, 2016) sonucuna ulaşılmıştır.

Son 40 yıl içerisinde kadınların STEM işgücüne katılımlarına yönelik büyük bir çaba sarf edilmesine rağmen, kadınların biyoloji, tıp ve sağlık bilimlerini seçme oranlarının mühendislik, fizik ve bilişim alanlarına göre daha fazla olduğu belirtilmektedir (National Center for Education Statistics, 2007). Benzer bir şekilde Türkiye'de 2002 ve 2012 yılları arasında yükseköğretimde STEM alanlarında, kadınlardan daha fazla erkek olduğu, özellikle mühendisliğin erkek egemen kariyer olarak görüldüğü tespit edilmiştir (Korkut-Owen, Kelecioğlu ve Owen, 2014). Araştırmalarda kız öğrencilerin STEM alanlarına yönelik ilgilerinin, lise yıllarında erkek öğrencilerin ilgilerine kıyasla daha hızlı bir şekilde azaldığ (Brotman ve Moore, 2008; Wells, Sanchez ve Attridge, 2007). Lise öğrencileri ile yapılan bir araştırmada, erkeklerin STEM kariyer ilgilerinin kızlara 
göre daha fazla olduğu, lise yıllarında bir STEM kariyeri ile ilgilenen erkeklerin oranının sabit kaldığı, kadınlarda ise bu oranın düştüğü tespit edilmiştir (Sadler vd., 2012). Ortaokul ve lise yıllarında kız öğrencilerin, fen ve teknoloji alanlarını gelecekteki kariyer hedefleri olarak görmedikleri belirtilmektedir (Lent vd., 2005). Başka bir araştırma sonucunda bütün eğitim kademelerinde, kız öğrencilerin mühendislik ve teknolojiye yönelik tutumlarının, erkek öğrencilere göre daha olumsuz olduğu belirlenmiştir (Unfried vd., 2014). Genel olarak araştırma sonuçlarına dayanarak, kadınların STEM kariyerlerinde yeterince temsil edilmediği sonucuna varllabilir.

\section{Sosyal Bilişsel Kariyer Kuramı (SBKK)}

Kariyer gelişimi ve kariyer seçim sürecinde bilişsel etmenlerin etkili olduğu ve bireylerin kendi kariyer süreçlerini yönlendirebilme kapasitelerinin bulunduğu düşüncelerine dayanan Sosyal Bilişsel Kariyer Kuramı (SBKK) Lent, Brown ve Hackett (1994) tarafından geliştirilmiştir. Bandura'nın (1986) sosyal bilişsel öğrenme kuramına dayanan SBKK, bireyin kariyer seçiminde bireysel, çevresel ve davranışsal değişkenler arasındaki ilişkinin etkili olduğunu vurgulamaktadır (Lent ve Brown, 2006). Söz konusu bu değişkenler temel olarak öz-yeterlik inançları, sonuç beklentileri, kişisel hedefler, ilgiler, çevresel destekler ve engeller ile kişisel eğilim olarak ifade edilmektedir (Lent, Sheu, Gloster ve Wilkins, 2010).

Bireyin akademik ve mesleki gelişiminin belirlenmesinde öz-yeterlik inançları, sonuç beklentileri ve kişisel hedefleri belirleme gibi değişkenlerin etkili olduğu belirtilmektedir (Lent vd., 1994). Bazı bireyler kariyer kararı verirken çevrelerindeki bireylerin destek ve rehberliğine ihtiyaç duymakta ve öz-yeterlik sorunu hissetmektedirler (Sauermann, 2005). Bu durum SBKK'nın bireysel değişkenlerinden biri olan öz-yeterliğin, kariyer kararı verme sürecindeki önemini vurgulamaktadır. Öz-yeterlik inancı bireyin, belirli bir alanda gerekli davranışı sergileyip sergileyemeyeceğine ilişkin algısı olarak tanımlanmaktadır. Sonuç beklentisi, bireyin sergilediği belirli bir davranışın sonucuyla ilgili kişisel beklentileri, kişisel hedefler ise belirli bir alana yönelme arzusu olarak ifade edilmektedir (Niles ve Harris-Bowlsbey, 2013). SBKK'na göre bireylerin kariyer ilgileri, temel 
olarak öz-yeterlik inançları ve sonuç beklentileri tarafından düzenlenmektedir. Bireyler kendilerini kişisel olarak yeterli bulduklarında ve olumlu sonuç beklediklerinde bir konuya ilişkin ilgileri sürmektedir (Lent vd., 1994).

STEM'e ilişkin tutum ve kariyer ilgisinin, SBKK olarak adlandırılan kariyer gelişim teorisinin temel bileşenleri olduğu (Lent vd, 2010) ve bireylerin STEM kariyerlerini tercih etmeleri konusunda SBKK'nın iyi bir bakış açısı sağladığı belirtilmektedir (Lent vd., 1994; Wang, 2013; Wang ve Degol, 2013). Literatürde STEM kariyerlerine yönelik ilginin, SBKK açısından ele alındığı araştırmalar yer almaktadır. Bu araştırmaların çoğunlukla lise öğrencileri (Lopez, Lent, Brown ve Gore, 1997; O'Brien, Martinez-Pons ve Kopala, 1999; Owen ve Çapan, 2017; Wang, 2013) ve üniversite öğrencileri (Ferry, Fouad ve Smith, 2000; Lent vd., 2001, 2003) ile gerçekleştirildiği görülmüştür. Örneğin lise öğrencileri ile yürütülen bir çalışmada, STEM alanlarını seçmede 12. sınıf matematik başarısı, alınan matematik ve fen derslerinin sayısı ve matematik öz-yeterlik inançlarının etkili olduğu belirlenmiştir (Wang, 2013). Lise öğrencilerinin STEM alanlarını seçmeyi düşünme nedenlerinin araştırıldığı diğer bir çalışmada, öğrencilerin müsbet ve doğal bilimlerini ve mühendislik, üretim ve yapı bilimleri eğitim alanlarını, seçmeyi düşünme ve düşünmeme nedenlerinin başında güçlü biçimde ilginin geldiği bulgusuna ulaşılmıştır. Araştırma sonucunda STEM alanlarında eğitim almayı seçmeyi ya da seçmemeyi düşünme nedenleri öz-yeterlik, sonuç beklentisi, kişisel hedefler ve sosyal/sistemik etmenler olarak belirlenmiştir (Owen ve Çapan, 2017). Araştırmalarda STEM kariyer seçiminde cinsiyetin yanı sıra öz-yeterlik, ilgi gibi faktörlerin de etkili olduğu belirtilmektedir (Betz, 2007; Ceci ve Williams, 2010).

Literatürde ortaokul düzeyinde fen, matematik ve mühendislik kariyerlerine yönelik ilginin, SBKK açısından ele alındığı araştırmalar da bulunmakla birlikte (Fouad ve Smith, 1996; Navarro, Flores ve Worthington, 2007) lise ve üniversite düzeyindeki araştırma sayısına göre az olduğu dikkat çekmiştir. Örneğin bir araştırmada ortaokul öğrencilerinin matematik ve fen öz-yeterliklerinin, matematik ve fene ilişkin sonuç beklentilerini, ilgilerini ve hedeflerini büyük oranda etkilediği bulunmuştur (Navarro vd., 2007). SBKK çerçevesinde kariyer tercihleri ya da ilgilerine yönelik tartışmaların, lise ve üniversite yılları ile sınırlandırılmasından (Lent vd., 1994) dolayı ortaokul öğrencileri ile yapılan çalışma sayısının, lise ve 
üniversite öğrencileri ile yapılan çalışma sayısına göre az olduğu düşünülmektedir (Navarro vd., 2007). Bununla birlikte kariyer tercihinin şekillendiği kritik bir dönem olması nedeni ile ortaokul yıllarının, ileriki yıllarda kariyere ilişkin alınan eğitim üzerinde güçlü bir etkiye sahip olduğu da belirtilmektedir (Fouad ve Smith, 1996; Turner ve Lapan, 2005). STEM kariyer hedefleri ve isteklerine yönelik kararlar ortaokul yıllarında alınmaktadır. Bu nedenle ortaokulda öğrencilerin STEM alanları ve kariyerleri hakkında bilgilendirilmesi, STEM kariyer ilgilerinin gelişimi ve doğru kariyer seçiminde etkili olacaktır (Knight ve Cunningham, 2004; Wyss, Heulskamp ve Siebert, 2012). Araştırma sonuçlarında, öğrencilerin ortaokul yıllarından başlayarak STEM kariyerlerine yönlendirilmesi gerektiğini belirtilmektedir (Christensen ve Knezek, 2017; Wyss vd., 2012). Genel olarak araştırmalarda, erkeklerin STEM kariyer ilgilerinin kızlara göre daha yüksek düzeyde olduğu, özellikle mühendislik ve teknoloji alanlarındaki kariyerleri erkeklerin kızlara oranla daha fazla seçtiği sonuçlarına ulaşılmıştır. Bu nedenle ortaokul öğrencilerinin STEM kariyer ilgilerine cinsiyetin etkisinin belirlenmesinin önemli olduğu düşünülmektedir. Öğrencilerin kariyer ilgilerinin erken yaşlarda belirlenmesi sayesinde, öğrencilere okullarda yeterli mesleki rehberlik hizmeti verilmesinin mümkün olacağı söylenebilir. Ortaokul düzeyinde STEM kariyerlerine yönelik ilginin, SBKK açısından ele alındığı araştırma sayısının, lise ve üniversite düzeyine göre daha az olduğu görüldüğünden bu araştırmaya ihtiyaç duyulmuştur. Araştırmanın problem cümlesi ‘SBKK açısından ortaokul öğrencilerinin STEM kariyer ilgileri, cinsiyete göre anlamlı farklılık göstermekte midir?' şeklinde belirlenmiştir. Bu doğrultuda araştırmada aşağıdaki alt problemlere cevap aranmıştır:

1. Öğrencilerin STEM kariyer ilgileri, cinsiyete göre anlamlı farklılık göstermekte midir?

2. Öğrencilerin STEM kariyer ilgileri, SBKK faktörlerinde cinsiyete göre anlamlı farklılık göstermekte midir?

3. Öğrencilerin STEM alanlarındaki kariyer ilgileri, SBKK faktörlerinde cinsiyetlerine göre anlamlı farklılık göstermekte midir? 


\section{Yöntem}

Araştırmada genel tarama modeli kullanılmıştır. Sosyal bilimlerde yaygın olarak kullanılan genel tarama modelindeki araştırmalar, geçmişte ya da halen var olan bir durumu var olduğu şekliyle betimlemeyi amaçlar (Karasar, 2009). Araştırmanın evrenini, 2016-2017 eğitim-öğretim yılında Ege bölgesindeki bir ilin, orta büyüklükteki bir ilçesinde bulunan devlet ortaokullarına devam eden öğrenciler oluşturmaktadır. Araştırmanın örneklemi ise bu ortaokullardan birinde öğrenim gören 218'i kız, 182'si erkek olmak üzere toplam 400 öğrenciden oluşmaktadır. Örneklemin belirlenmesinde amaçlı örnekleme çeşitlerinden biri olan kolay ulaşılabilir durum örneklemesi kullanılmıştır. Bu örnekleme yönteminde araştırmacı, yakın ve erişilmesi kolay olan bir durumu seçtiğinden araştırmaya hız ve pratiklik kazandırmaktadır (Yıldırım ve Şimşek, 2016). Araştırmanın örneklemine ait demografik bilgilerin dağılımı Tablo 1'de verilmiştir.

Tablo 1. Örnekleme ait demografik bilgiler

\begin{tabular}{llll}
\hline Sinif düzeyi & $\mathbf{K i z}$ & Erkek & Toplam \\
\hline 5 & 47 & 53 & 100 \\
\hline 6 & 58 & 42 & 100 \\
\hline 7 & 56 & 44 & 100 \\
\hline 8 & 57 & 43 & 100 \\
\hline Toplam & 218 & 182 & 400 \\
\hline
\end{tabular}

\section{Veri Toplama Aract}

Araştırmada ortaokul öğrencilerinin STEM kariyer ilgilerini belirlemek amacıyla Kier, Blanchard, Osborne ve Albert (2014) tarafından geliştirilen, Koyunlu Ünlü, Dökme ve Ünlü (2016) tarafından Türkçeye uyarlanan STEM Kariyer İlgi Anketi kullanılmıştır. Ankette yer alan maddeler, Sosyal Bilişsel Kariyer Kuramı'na dayanarak oluşturulmuştur. Türkçeye uyarlanan anket 5'li likert tarzında olup fen, teknoloji, mühendislik ve matematik olmak üzere dört alt boyuttan ve her alt boyutta 10 madde olmak üzere 40 maddeden oluşmaktadır. Bu 10 maddenin, altı farklı SBKK faktörüne dağılımı; öz yeterlik (2), kişisel hedef (2), sonuç beklentisi (2), ilgi (2), çevresel destek ve engeller (1) ve kişisel eğilim (1) şeklindedir. Anketin mühendislik boyutundaki SBKK faktörlerine ilişkin maddeler Tablo 2' de 
verilmiştir. Diğer boyutlarda boyut ismi değişmekte ve benzer içerikteki maddelerden oluşmaktadır.

Tablo 2. STEM kariyer ilgi anketinin mühendislik alt boyutundaki maddelerin SBKK faktörlerine göre dağılımı

\begin{tabular}{ll}
\hline SBKK faktörü & Madde \\
\hline Öz-yeterlik & $\begin{array}{l}\text { Mühendislik ile ilgili etkinliklerde iyiyimdir. } \\
\text { Mühendislik ile ilgili etkinlikleri yapabilirim. }\end{array}$ \\
\hline Kişisel hedef & $\begin{array}{l}\text { Mühendislik ile ilgili etkinlikleri meslek seçimimde kullanacağım. } \\
\text { Mühendislik içeren etkinlikler üzerinde çok çalışacağım. }\end{array}$ \\
\hline Sonuç beklentisi & $\begin{array}{l}\text { Eğer mühendislik hakkında çok şey öğrenebilirsem, birçok farklı mes- } \\
\text { lek yapabilirim. } \\
\text { Mühendislik ile ilgili bir meslek seçimim anne ve babamı sevindirir. }\end{array}$ \\
\hline İlgi & $\begin{array}{l}\text { Mühendislik ile ilgili mesleklere ilgi duyarım. } \\
\text { Mühendislik ile ilgili etkinlikleri severim. }\end{array}$ \\
\hline $\begin{array}{l}\text { Çevresel destek ve } \\
\text { engeller }\end{array}$ & Meslek olarak mühendisliği seçmiş ve örnek aldığım biri vardır. \\
\hline Kişisel eğilim & Mühendislerle çekinmeden konuşabilirim. \\
\hline
\end{tabular}

Anketin genelinin Cronbach alpha değeri .93, alt boyutların ise sırasıyla .86, .88, .94 ve .90 olarak belirtilmiştir (Koyunlu Ünlü vd., 2016). Bu araştırmada ise anketin genelinin Cronbach alpha değeri .86, alt boyutların ise sırasıyla $.80, .85, .81$ ve .83 olarak hesaplanmıştır. Büyüköztürk'e (2017) göre Cronbach alpha değerinin .70 ve üzerinde olması ölçme arac1nın güvenilirliği için kabul edilebilir olduğundan anketin güvenilir olduğu söylenebilir.

\section{Veri Analizi}

Öğrencilerin STEM kariyer ilgi anketinden elde ettikleri puanların normal dağılım gösterip göstermediğini belirlemek için çarpıklık ve basıklık değerlerine bakılmıştır. Analiz sonucunda çarpıklık basıklık değerleri sırası ile kız öğrenciler için (-.255, -.206), erkek öğrenciler için $(-.499, .222)$ olarak hesaplanmıştır. Büyüköztürk'e göre (2017), puanların dağılımında çarpıklık ve basıklık değerleri -1 ile +1 değerleri arasında ise puanların normal dağılım gösterdiği söylenebilir ve parametrik testler kullanılabilir. 
Hesaplanan çarpıklık ve basıklık değerlerine göre, kız ve erkek öğrencilerin anketten elde ettikleri verilerin normal dağıldığı belirlenmiş ve analizlerde bağımsız örneklemler için $t$ testi kullanılmıştır.

\section{Bulgular}

Öğrencilerin STEM Kariyer İlgilerinin Cinsiyete Göre Değişimine İlişkin Bulgular

Araştırmanın 'Öğrencilerin STEM kariyer ilgileri cinsiyete göre anlamlı farklılık göstermekte midir?' şeklindeki birinci alt problemine yanıt bulabilmek amacı ile STEM kariyer ilgi anketinin alt boyutlarından ve tamamından elde edilen veriler cinsiyete göre bağımsız örneklem $t$ testi ile analiz edilmiştir. Analiz sonuçları Tablo 3'te sunulmuştur.

Tablo 3. STEM kariyer ilgi anketi ve alt boyutlarna ait cinsiyete göre t-testi analiz sonuçları

\begin{tabular}{|c|c|c|c|c|c|c|}
\hline Anket & Cinsiyet & $\mathbf{N}$ & $\overline{\boldsymbol{X}}$ & sd & $t$ & $\mathrm{p}$ \\
\hline \multirow[t]{2}{*}{ Fen } & $\mathrm{K}_{1 \mathrm{z}}$ & 218 & 4.13 & 398 & 2.03 & $.04^{*}$ \\
\hline & Erkek & 182 & 4.03 & & & \\
\hline \multirow[t]{2}{*}{ Teknoloji } & $\mathrm{K}_{1 \mathrm{Z}}$ & 218 & 3.91 & 398 & -2.36 & $.01^{*}$ \\
\hline & Erkek & 182 & 4.18 & & & \\
\hline \multirow[t]{2}{*}{ Mühendislik } & $\mathrm{K}_{12}$ & 218 & 3.42 & 398 & -4.19 & $.00^{*}$ \\
\hline & Erkek & 182 & 3.98 & & & \\
\hline \multirow[t]{2}{*}{ Matematik } & $\mathrm{K} 1 \mathrm{z}$ & 218 & 4.22 & 398 & 1.96 & $.04^{*}$ \\
\hline & Erkek & 182 & 4.09 & & & \\
\hline \multirow[t]{2}{*}{ STEM } & $\mathrm{K} 1 \mathrm{Z}$ & 218 & 3.76 & 398 & -1.06 & $.03^{*}$ \\
\hline & Erkek & 182 & 3.92 & & & \\
\hline
\end{tabular}

${ }^{*} p<.05$

Tablo 3'e göre öğrencilerin kariyer ilgileri, fen [ $\left.\mathrm{t}_{(398)}=2.03 ; \mathrm{p}<.05\right]$, teknoloji $[\mathrm{t}(398)=-2.36 ; \mathrm{p}<.05]$, mühendislik [ $\mathrm{t}(398)=-4.19 ; \mathrm{p}<.05]$ ve matematik $\left[\mathrm{t}_{(398)}=1.96 ; \mathrm{p}<.05\right]$ alanlarında cinsiyete göre istatistiksel olarak anlamlı farklılık göstermektedir. Ortalama ilgi puanlarına bakıldığında farklılığın, fen ve matematik alanlarında kız öğrenciler lehine, teknoloji ve mühendislik alanlarında ise erkek öğrenciler lehine olduğu görülmektedir. Anketin tamamından elde edilen verilerin analiz sonuçlarına göre, öğrencilerin STEM kariyer ilgilerinin de $\left[\mathrm{t}_{(398)}=-1.06 ; \mathrm{p}<.05\right]$ cinsiyete göre anlamlı 
farkl1lık gösterdiği bulunmuştur. STEM kariyer ilgisi ortalama puanlarına göre erkek öğrencilerin STEM kariyer ilgilerinin, kız öğrencilerin STEM kariyer ilgilerine göre daha yüksek olduğu tespit edilmiştir.

\section{Öğrencilerin STEM Kariyer İlgilerinin SBKK Faktörlerinde Cinsiyete Göre Değişimine İlişkin Bulgular}

Araştırmanın “Öğrencilerin STEM kariyer ilgileri SBKK faktörlerinde cinsiyete göre anlamlı farklılık göstermekte midir?" şeklindeki ikinci alt problemine yanıt bulabilmek amacı ile anketin tamamına ilişkin sosyal bilişsel meslek faktörlerinin her birinden elde edilen ortalama puanlar cinsiyete göre bağımsız örneklem $t$ testi ile analiz edilmiştir. Analiz sonuçları Tablo 4'te sunulmuştur.

Tablo 4. STEM kariyer ilgisine yönelik sosyal bilişsel meslek faktörlerinin cinsiyete göre t testi sonuçları

\begin{tabular}{|c|c|c|c|c|c|c|}
\hline Sosyal bilişsel meslek faktörü & Cinsiyet & $\mathbf{N}$ & $\bar{X}$ & sd & $\mathbf{t}$ & $\mathbf{p}$ \\
\hline \multirow[t]{2}{*}{ Öz yeterlik } & K1z & 218 & 3.94 & 398 & -3.14 & $.00^{*}$ \\
\hline & Erkek & 182 & 4.05 & & & \\
\hline \multirow[t]{2}{*}{ Kişisel hedef } & $\mathrm{K}_{1 \mathrm{Z}}$ & 218 & 3.89 & 398 & -1.14 & .25 \\
\hline & Erkek & 182 & 3.93 & & & \\
\hline \multirow[t]{2}{*}{ Sonuç beklentisi } & $\mathrm{K}_{12}$ & 218 & 4.09 & 398 & -.75 & .45 \\
\hline & Erkek & 182 & 4.12 & & & \\
\hline \multirow[t]{2}{*}{ İlgi } & $\mathrm{K} 1 \mathrm{Z}$ & 218 & 3.89 & 398 & -3.13 & $.00^{*}$ \\
\hline & Erkek & 182 & 4.01 & & & \\
\hline \multirow[t]{2}{*}{ Çevresel Destek ve Engeller } & $\mathrm{K}_{1 \mathrm{Z}}$ & 218 & 3.28 & 398 & -1.62 & .11 \\
\hline & Erkek & 182 & 3.37 & & & \\
\hline \multirow[t]{2}{*}{ Kişisel eğilim } & $\mathrm{K}_{1 \mathrm{Z}}$ & 218 & 4.00 & 398 & -.022 & .98 \\
\hline & Erkek & 182 & 4.00 & & & \\
\hline
\end{tabular}

${ }^{*} p<.05$

Tablo 4'e göre öğrencilerin STEM kariyer ilgileri, SBKK'nın öz-yeterlik $\left[\mathrm{t}_{(398)}=-3.14 ; \mathrm{p}<.05\right]$ ve ilgi $[\mathrm{t}(398)=-3.13 ; \mathrm{p}<.05]$ faktörlerinde cinsiyete göre anlamlı farklılık göstermektedir. Ortalama puanlara bakıldığında erkek öğrencilerin STEM kariyer öz-yeterliklerinin ve ilgilerinin kız öğrencilere göre daha yüksek olduğu görülmektedir. STEM kariyer ilgilerinin SBKK'nın kişisel hedef $[\mathrm{t}(398)=-1.14 ; \mathrm{p}>.05]$, sonuç beklentisi [ $\mathrm{t}(398)=-.75$; $\mathrm{p}>$.05], çevresel destek ve engeller [ $\left.\mathrm{t}_{(398)}=-1.62 ; \mathrm{p}>.05\right]$ ve kişisel eğilim 
$[\mathrm{t}(398)=-.022 ; \mathrm{p}>$.05] faktörlerinde cinsiyete göre anlaml farklllık göstermediği belirlenmiştir. Buna göre erkek öğrencilerin STEM kariyer ilgilerinin kız öğrencilere göre daha olumlu olmasında, SBKK açısından STEM kariyerlerine yönelik öz-yeterlik ve ilgi düzeylerinin etkili olduğu söylenebilir.

\section{Öğrencilerin STEM Alanlarındaki Kariyer İlgilerinin SBKK Faktörlerinde Cinsiyete Göre Değişimine İlişskin Bulgular}

Araştırmanın 'Öğrencilerin STEM alanlarındaki kariyer ilgileri, SBKK faktörlerinde cinsiyetlerine göre anlamlı farklılık göstermekte midir?' şeklindeki üçüncü alt problemine yanıt bulabilmek amacı ile STEM kariyer ilgi anketinin alt boyutlarında, SBKK faktörlerine ilişkin olarak elde edilen ortalama puanlar, cinsiyete göre bağımsız örneklem $t$ testi ile analiz edilmiştir. Analiz sonuçları sırası ile Tablo 5, Tablo 6, Tablo 7, Tablo 8, Tablo 9 ve Tablo 10'da sunulmuştur. Öğrencilerin anketin alt boyutlarına ilişkin özyeterlik düzeylerinin, cinsiyete göre bağımsız örneklem $t$ testi analiz sonuçları Tablo 5'de verilmiştir.

Tablo 5. STEM kariyer ilgi anketi alt boyutlarna ait öz yeterlik düzeyinin cinsiyete göre t testi analiz sonuçları

\begin{tabular}{|c|c|c|c|c|c|c|c|}
\hline $\begin{array}{l}\text { Sosyal Bilişsel } \\
\text { Meslek Faktörü }\end{array}$ & Alt Boyutlar & Cinsiyet & $\mathbf{N}$ & $\overline{\boldsymbol{X}}$ & sd & $\mathbf{t}$ & p \\
\hline \multirow[t]{8}{*}{ Öz yeterlik } & \multirow[t]{2}{*}{ Fen } & Kiz & 218 & 4.19 & \multirow[t]{2}{*}{398} & \multirow[t]{2}{*}{0.77} & \multirow[t]{2}{*}{.44} \\
\hline & & Erkek & 182 & 4.15 & & & \\
\hline & \multirow[t]{2}{*}{ Teknoloji } & $\mathrm{K}_{1 z}$ & 218 & 4.09 & \multirow[t]{2}{*}{398} & \multirow[t]{2}{*}{-4.45} & \multirow[t]{2}{*}{$.00^{*}$} \\
\hline & & Erkek & 182 & 4.29 & & & \\
\hline & \multirow[t]{2}{*}{ Mühendislik } & $\mathrm{K}_{1 \mathrm{Z}}$ & 218 & 3.31 & \multirow[t]{2}{*}{398} & \multirow[t]{2}{*}{-6.44} & \multirow[t]{2}{*}{$.00^{*}$} \\
\hline & & Erkek & 182 & 3.70 & & & \\
\hline & \multirow[t]{2}{*}{ Matematik } & $\mathrm{K}_{1 \mathrm{Z}}$ & 218 & 4.19 & \multirow[t]{2}{*}{398} & \multirow[t]{2}{*}{2.02} & \multirow[t]{2}{*}{$.04^{*}$} \\
\hline & & Erkek & 182 & 4.06 & & & \\
\hline
\end{tabular}

${ }^{{ }^{*} p<.05}$

Tablo 5'e göre cinsiyete göre öz-yeterlik düzeyleri teknoloji $[\mathrm{t}(398)=-4.45$; $\mathrm{p}<.05]$, mühendislik $[\mathrm{t}(398)=-6.44 ; \mathrm{p}<.05]$ ve matematik $[\mathrm{t}(398)=2.02 ; \mathrm{p}<.05]$ alt boyutlarında anlamlı farklılık göstermektedir. Ortalama puanlara bakıld1ğında teknoloji ve mühendislik alanlarında erkek öğrencilerin öz-yeterlik düzeylerinin kızlara göre daha yüksek olduğu, matematik alanında ise kız 
öğrencilerin öz-yeterlik düzeylerinin erkeklere göre daha yüksek olduğu görülmektedir. Tablo 5'e göre fen alanına ilişkin öz-yeterlik düzeyinin cinsiyete göre anlamlı olarak farklılaşmadığ $\breve{~}^{\mathrm{t}(398)}=0.77 ; \mathrm{p}>$.05] belirlenmiştir. Öğrencilerin anketin alt boyutlarına ilişkin kişisel hedef düzeylerinin cinsiyete göre bağımsız örneklem $t$ testi analiz sonuçları Tablo 6 'da verilmiştir.

Tablo 6. STEM kariyer ilgi anketi alt boyutlarna ait kişisel hedef düzeyinin cinsiyete göre t testi analiz sonuçları

\begin{tabular}{|c|c|c|c|c|c|c|c|}
\hline $\begin{array}{l}\text { Sosyal Bilişsel } \\
\text { Meslek Faktörü }\end{array}$ & Alt Boyutlar & Cinsiyet & $\mathbf{N}$ & $\bar{X}$ & sd & $t$ & p \\
\hline \multirow[t]{8}{*}{ Kişisel Hedef } & \multirow[t]{2}{*}{ Fen } & $\mathrm{K}_{1 z}$ & 218 & 4.17 & \multirow[t]{2}{*}{398} & \multirow[t]{2}{*}{3.10} & \multirow[t]{2}{*}{$.00^{\prime}$} \\
\hline & & Erkek & 182 & 4.02 & & & \\
\hline & \multirow[t]{2}{*}{ Teknoloji } & $\mathrm{K}_{1 \mathrm{Z}}$ & 218 & 3.85 & \multirow[t]{2}{*}{398} & \multirow[t]{2}{*}{-2.92} & \multirow[t]{2}{*}{$.00^{\circ}$} \\
\hline & & Erkek & 182 & 4.00 & & & \\
\hline & \multirow[t]{2}{*}{ Mühendislik } & $\mathrm{K} 1 \mathrm{z}$ & 218 & 3.20 & \multirow[t]{2}{*}{398} & \multirow[t]{2}{*}{-5.25} & \multirow[t]{2}{*}{$.00^{\prime}$} \\
\hline & & Erkek & 182 & 3.56 & & & \\
\hline & \multirow[t]{2}{*}{ Matematik } & $\mathrm{K} 1 \mathrm{z}$ & 218 & 4.33 & \multirow[t]{2}{*}{398} & \multirow[t]{2}{*}{3.26} & \multirow[t]{2}{*}{$.00^{*}$} \\
\hline & & Erkek & 182 & 4.15 & & & \\
\hline
\end{tabular}

${ }^{*} p<.05$

Tablo 6'daki analiz sonuçlarına göre öğrencilerin kişisel hedef düzeyleri fen [ $\left.\mathrm{t}_{(398)}=3.10 ; \mathrm{p}<.05\right]$, teknoloji [ $\left.\mathrm{t}(398)=-2.92 ; \mathrm{p}<.05\right]$, mühendislik [ $\mathrm{t}(398)=-$ 5.25; $\mathrm{p}<.05]$ ve matematik $[\mathrm{t}(398)=3.26 ; \mathrm{p}<.05]$ alanlarında cinsiyete göre anlamlı farklılık göstermektedir. Tablo 6 'daki ortalamalara bakıldığında fen ve matematik alanlarında kız öğrencilerin kişisel hedef düzeylerinin, erkek öğrencilere göre daha yüksek olduğu görülmektedir. Teknoloji ve mühendislik alanlarında ise erkek öğrencilerin kişisel hedef düzeylerinin, kız öğrencilere göre daha yüksek olduğu belirlenmiştir. Öğrencilerin anketin alt boyutlarına ilişkin sonuç beklentisi düzeylerinin cinsiyete göre bağımsız örneklem t testi analiz sonuçları Tablo 7'de verilmiştir. 
Tablo 7. STEM kariyer ilgi anketi alt boyutlarna ait sonuç beklentisi düzeyinin cinsiyete göre t testi analiz sonuçlarn

\begin{tabular}{|c|c|c|c|c|c|c|c|}
\hline $\begin{array}{l}\text { Sosyal Bilişsel } \\
\text { Meslek Faktörü }\end{array}$ & Alt Boyutlar & Cinsiyet & $\mathbf{N}$ & $\bar{X}$ & sd & $t$ & p \\
\hline \multirow[t]{8}{*}{ Sonuç beklentisi } & \multirow[t]{2}{*}{ Fen } & K1z & 218 & 4.22 & \multirow[t]{2}{*}{398} & \multirow[t]{2}{*}{2.48} & \multirow[t]{2}{*}{$.01^{*}$} \\
\hline & & Erkek & 182 & 4.09 & & & \\
\hline & \multirow[t]{2}{*}{ Teknoloji } & $\mathrm{K}_{1 z}$ & 218 & 3.90 & \multirow[t]{2}{*}{398} & \multirow[t]{2}{*}{-3.20} & \multirow[t]{2}{*}{$.00^{*}$} \\
\hline & & Erkek & 182 & 4.08 & & & \\
\hline & \multirow[t]{2}{*}{ Mühendislik } & $\mathrm{K}_{1 Z}$ & 218 & 3.82 & \multirow[t]{2}{*}{398} & \multirow[t]{2}{*}{-3.33} & \multirow[t]{2}{*}{$.00^{*}$} \\
\hline & & Erkek & 182 & 4.02 & & & \\
\hline & \multirow[t]{2}{*}{ Matematik } & $\mathrm{K}_{1 Z}$ & 218 & 4.41 & \multirow[t]{2}{*}{398} & \multirow[t]{2}{*}{2.62} & \multirow[t]{2}{*}{$.00^{*}$} \\
\hline & & Erkek & 182 & 4.28 & & & \\
\hline
\end{tabular}

${ }^{*} p<.05$

Tablo 7'deki analiz sonuçlarına göre öğrencilerin sonuç beklentisi, fen [ $\left.\mathrm{t}_{(398)}=2.48 ; \mathrm{p}<.05\right]$, teknoloji $\left[\mathrm{t}_{(398)}=-3.20 ; \mathrm{p}<.05\right]$, mühendislik $\left[\mathrm{t}_{(398)}=-3.33\right.$; $\mathrm{p}<.05]$ ve matematik [ $\mathrm{t}(398)=2.62 ; \mathrm{p}<.05]$ alanlarında cinsiyete göre anlaml farklılık göstermektedir. Tablo 7 'deki ortalama değerlere göre fen ve matematik alanlarında kız öğrencilerin sonuç beklentilerinin, erkek öğrencilere göre daha yüksek olduğu görülmektedir. Teknoloji ve mühendislik alanlarında ise erkek öğrencilerin sonuç beklentilerinin, kız öğrencilere göre daha yüksek olduğu belirlenmiştir. Öğrencilerin anketin alt boyutlarına ilişkin ilgi düzeylerinin cinsiyete göre bağımsız örneklem $t$ testi analiz sonuçları Tablo 8' de verilmiştir.

Tablo 8. STEM kariyer ilgi anketi alt boyutlarna ait ilgi düzeyinin cinsiyete göre $t$ testi analiz sonuçlan

\begin{tabular}{|c|c|c|c|c|c|c|c|}
\hline $\begin{array}{l}\text { Sosyal Bilişsel } \\
\text { Meslek Faktörü }\end{array}$ & Alt Boyutlar & Cinsiyet & $\mathbf{N}$ & $\bar{X}$ & sd & $t$ & p \\
\hline \multirow[t]{8}{*}{ İlgi } & \multirow[t]{2}{*}{ Fen } & $\mathrm{K}_{1 z}$ & 218 & 4.20 & \multirow[t]{2}{*}{398} & \multirow[t]{2}{*}{0.91} & \multirow[t]{2}{*}{.36} \\
\hline & & Erkek & 182 & 4.15 & & & \\
\hline & \multirow[t]{2}{*}{ Teknoloji } & $\mathrm{K}_{1 \mathrm{Z}}$ & 218 & 3.94 & \multirow[t]{2}{*}{398} & \multirow[t]{2}{*}{-2.93} & \multirow[t]{2}{*}{$.00^{*}$} \\
\hline & & Erkek & 182 & 4.10 & & & \\
\hline & \multirow[t]{2}{*}{ Mühendislik } & $\mathrm{K}_{12}$ & 218 & 3.33 & \multirow[t]{2}{*}{398} & \multirow[t]{2}{*}{-7.75} & \multirow[t]{2}{*}{$.00^{*}$} \\
\hline & & Erkek & 182 & 3.82 & & & \\
\hline & \multirow[t]{2}{*}{ Matematik } & Kiz & 218 & 4.10 & \multirow[t]{2}{*}{398} & \multirow[t]{2}{*}{1.59} & \multirow[t]{2}{*}{.11} \\
\hline & & Erkek & 182 & 4.00 & & & \\
\hline
\end{tabular}

${ }^{{ }^{*} p<.05}$

Tablo 8'deki analiz sonuçlarına göre öğrencilerin ilgi düzeyleri fen $\left[\mathrm{t}_{(398)}=0.91 ; \mathrm{p}>.05\right]$ ve matematik $\left[\mathrm{t}_{(398)}=1.59 ; \mathrm{p}>.05\right]$ alanlarında cinsiyete 
göre anlamlı farkl1lık göstermemektedir. Teknoloji $\left[\mathrm{t}_{(398)}=-2.93 ; \mathrm{p}<.05\right]$ ve mühendislik [ $\left.\mathrm{t}_{(398)}=-7.75 ; \mathrm{p}<.05\right]$ alanlarına yönelik ilgi düzeyi ise erkek öğrenciler lehine anlamlı farklılık göstermektedir. Öğrencilerin anketin alt boyutlarına ilişkin çevresel destek ve engel düzeylerinin cinsiyete göre bağımsız örneklem t testi analiz sonuçları Tablo 9'da verilmiştir.

Tablo 9. STEM kariyer ilgi anketi alt boyutlarına ait çevresel destek ve engel düzeyinin cinsiyete göre t testi analiz sonuçları

\begin{tabular}{|c|c|c|c|c|c|c|c|}
\hline $\begin{array}{l}\text { Sosyal Bilişsel } \\
\text { Meslek Faktörü }\end{array}$ & Alt Boyutlar & Cinsiyet & $\mathbf{N}$ & $\bar{X}$ & sd & $t$ & $\mathrm{p}$ \\
\hline \multirow{8}{*}{$\begin{array}{l}\text { Çevresel Destek ve En- } \\
\text { geller }\end{array}$} & \multirow[t]{2}{*}{ Fen } & $\mathrm{K}_{1 z}$ & 218 & 3.42 & \multirow[t]{2}{*}{398} & \multirow[t]{2}{*}{3.16} & \multirow[t]{2}{*}{$.00^{*}$} \\
\hline & & Erkek & 182 & 3.16 & & & \\
\hline & \multirow[t]{2}{*}{ Teknoloji } & $\mathrm{K}_{1 \mathrm{Z}}$ & 218 & 3.50 & \multirow[t]{2}{*}{398} & \multirow[t]{2}{*}{-1.82} & \multirow[t]{2}{*}{.07} \\
\hline & & Erkek & 182 & 3.63 & & & \\
\hline & \multirow[t]{2}{*}{ Mühendislik } & $\mathrm{K} 1 \mathrm{z}$ & 218 & 2.79 & \multirow[t]{2}{*}{398} & \multirow[t]{2}{*}{-5.29} & \multirow[t]{2}{*}{$.00^{*}$} \\
\hline & & Erkek & 182 & 3.23 & & & \\
\hline & \multirow[t]{2}{*}{ Matematik } & $\mathrm{K}_{12}$ & 218 & 3.42 & \multirow[t]{2}{*}{398} & \multirow[t]{2}{*}{-0.55} & \multirow[t]{2}{*}{.58} \\
\hline & & Erkek & 182 & 3.47 & & & \\
\hline
\end{tabular}

${ }^{{ }^{*} p<.05}$

Tablo 9'daki analiz sonuçlarına göre, çevresel destek ve engel düzeyi teknoloji [ $\left.\mathrm{t}_{(398)}=-1.82 ; \mathrm{p}>.05\right]$ ve matematik $\left[\mathrm{t}_{(398)}=-0.55 ; \mathrm{p}>.05\right]$ alanlarında cinsiyete göre anlamlı farkl1lık göstermemektedir. Fen [ $\left.\mathrm{t}_{(398)}=3.16 ; \mathrm{p}<.05\right]$ ve mühendislik $[\mathrm{t}(398)=-5.29 ; \mathrm{p}<.05]$ alanlarında ise çevresel destek ve engel düzeyinin cinsiyete göre anlamlı farklılık gösterdiği belirlenmiştir. Tablo 9'daki ortalamalara göre çevresel destek ve engel düzeyi fen boyutunda kız öğrenciler lehine, mühendislik boyutunda ise erkek öğrenciler lehine anlamlı farklılık göstermektedir. Öğrencilerin anketin alt boyutlarına ilişkin kişisel eğilim düzeylerinin, cinsiyete göre bağımsız örneklem $t$ testi analiz sonuçları Tablo 10'da verilmiştir.

Tablo 10'daki analiz sonuçlarına göre kişisel eğilim düzeyi teknoloji [ $\left.\mathrm{t}_{(398)=-1.55 ;} \mathrm{p}>.05\right]$, mühendislik [ $\left.\mathrm{t}(398)=-1.43 ; \mathrm{p}>.05\right]$ ve matematik $[\mathrm{t}(398)=0.74 ; \mathrm{p}>$.05] alanlarında cinsiyete göre anlamlı farklılık göstermez$k e n$, fen $[\mathrm{t}(398)=2.42 ; \mathrm{p}<.05]$ alanında cinsiyete göre anlamlı farklılık göstermektedir. Fen alanında kız öğrencilerin kişisel eğilimlerinin, erkek öğrencilerin kişisel eğilimlerine göre daha yüksek olduğu belirlenmiştir. 
Tablo 10. STEM kariyer ilgi anketi alt boyutlarna ait kişisel eğilim düzeyinin cinsiyete göre t testi analiz sonuçlarn

\begin{tabular}{|c|c|c|c|c|c|c|c|}
\hline $\begin{array}{l}\text { Sosyal Bilişsel } \\
\text { Meslek Faktörü }\end{array}$ & Alt Boyutlar & Cinsiyet & $\mathbf{N}$ & $\overline{\bar{X}}$ & sd & $t$ & $p$ \\
\hline \multirow[t]{8}{*}{ Kişisel Eğilim } & \multirow[t]{2}{*}{ Fen } & $\mathrm{K}_{1 z}$ & 218 & 4.16 & \multirow[t]{2}{*}{398} & \multirow[t]{2}{*}{2.42} & \multirow[t]{2}{*}{$.01^{*}$} \\
\hline & & Erkek & 182 & 4.00 & & & \\
\hline & \multirow[t]{2}{*}{ Teknoloji } & $\mathrm{K}_{12}$ & 218 & 3.92 & \multirow[t]{2}{*}{398} & \multirow[t]{2}{*}{-1.55} & \multirow[t]{2}{*}{.12} \\
\hline & & Erkek & 182 & 4.03 & & & \\
\hline & \multirow[t]{2}{*}{ Mühendislik } & $\mathrm{K}_{1 \mathrm{z}}$ & 218 & 3.77 & \multirow[t]{2}{*}{398} & \multirow[t]{2}{*}{-1.43} & \multirow[t]{2}{*}{.15} \\
\hline & & Erkek & 182 & 3.88 & & & \\
\hline & \multirow[t]{2}{*}{ Matematik } & $\mathrm{K}_{1 \mathrm{Z}}$ & 218 & 4.16 & \multirow[t]{2}{*}{398} & \multirow[t]{2}{*}{0.74} & \multirow[t]{2}{*}{.46} \\
\hline & & Erkek & 182 & 4.10 & & & \\
\hline
\end{tabular}

${ }^{*} p<.05$

\section{Tartışma}

Ortaokul öğrencilerinin STEM kariyer ilgilerine cinsiyetin etkisinin, sosyal bilişsel kariyer kuramı açısından değerlendirilmesini amaçlayan bu araştırmada üç probleme yanıt aranmıştır. Bunlardan ilki cinsiyetin STEM kariyer ilgisi üzerinde anlamlı bir etkisinin olup olmadığıdır. Araştırma sonucunda erkek öğrencilerin STEM kariyer ilgilerinin, kız öğrencilere göre daha olumlu olduğu belirlenmiştir. Literatürde yer alan diğer araştırma sonuçları da bu bulguyu desteklemektedir (Christensen ve Knezek, 2017; Knezek vd., 2011; Sadler vd., 2012; Su vd., 2009; Unfried vd., 2014). $\mathrm{Bu}$ bulgudan farklı olarak bir araştırma sonucunda, STEM kariyer ilgisinin cinsiyete göre farklılık göstermediği belirlenmiştir (Yerdelen vd., 2016). Araştırma sonucunda anketin alt boyutlarını oluşturan STEM alanlarına ilişkin ilgi düzeyinin, fen ve matematik alanlarında kız öğrenciler lehine, teknoloji ve mühendislik alanlarında ise erkek öğrenciler lehine anlamlı farklılık gösterdiği belirlenmiştir. Dolayısı ile kız öğrencilerin STEM kariyer ilgilerinin erkek öğrencilere göre olumsuz olmasının temelinde, mühendislik ve teknoloji alanlarındaki kariyer ilgilerinin erkek öğrencilere göre daha düşük olmasının olduğu söylenebilir. Benzer olarak araştırmalarda STEM kariyer eşitsizliğinin kızlar aleyhine bilimden çok mühendislikte açıldığı (Sadler vd., 2012), ortaokul ve lise yıllarında kız ögrrencilerin, fen ve teknoloji alanlarını gelecekteki kariyer hedefleri olarak görmedikleri (Lent vd., 2005) belirtilmektedir. 
Araştırmada yanıt aranan ikinci problem durumu, öğrencilerin STEM kariyer ilgilerinin SBKK faktörlerinde cinsiyete göre farklılık gösterip göstermediğidir. Araştırma sonucunda, öğrencilerin STEM kariyerlerine ilişkin öz-yeterlik ve ilgi düzeylerinin cinsiyete göre anlamlı farklılık gösterdiği belirlenmiştir. Ortalama puanlara göre erkek öğrencilerin STEM kariyerlerine yönelik öz-yeterliklerinin ve ilgilerinin, kız öğrencilere göre daha yüksek olduğu belirlenmiştir. Dolayısı ile erkek öğrencilerin STEM kariyerlerine yönelik öz-yeterlik ve ilgi düzeylerinin, kız öğrencilere göre daha olumlu olmasının, STEM kariyer ilgilerinin de kız öğrencilere göre daha olumlu olması sonucunu doğurduğu ifade edilebilir.

Araştırmada cevap aranan sonuncu problem, öğrencilerin cinsiyetlerine göre STEM alanlarındaki kariyer ilgilerinin, SBKK faktörlerinde anlamlı farklılık gösterip göstermediğidir. Araştırmada öz-yeterlik düzeylerinin cinsiyete göre fen alanında farklılık göstermezken, teknoloji, mühendislik ve matematik alanlarında anlamlı farklılık gösterdiği bulunmuştur. Söz konusu farklılığın teknoloji ve mühendislik alanlarında erkek öğrenciler lehine, matematik alanında ise kız öğrenciler lehine olduğu görülmüştür. Bu bulgudan farklı olarak birkaç araştırmada, kadınların fen ve matematik alanlarında erkeklere göre daha düşük öz-yeterliğe sahip oldukları ve bu alanlardaki kariyerleri daha az tercih ettikleri sonucuna varılmıştır (Betz ve Hackett, 1983; Hackett,1985). Araştırmada ulaşılan, erkek öğrencilerin STEM kariyer öz-yeterliklerinin kızlara göre daha yüksek olması bulgusu, erkek öğrencilerin teknoloji ve mühendislik alanlarına yönelik öz-yeterliklerinin, kız öğrencilere göre yüksek olması bulgusu ile açıklanabilir. Mühendislik ve teknoloji kariyerlerindeki rol modeller öğrencilerin bu kariyerlere ilişkin öz-yeterlikleri üzerinde etkilidir. Çevresel destek ve engel olarak tanımlanan rol modellerin, Türkiye' de mühendislik erkek egemen kariyer olarak görüldügün̈en (Korkut-Owen vd., 2014) çoğunlukla erkek olduğu ifade edilebilir. Dolayısı ile kız öğrencilerin mühendislik alanındaki öz-yeterliklerinin düşük olmasının nedenlerinden birisi, bu alanda yeterli rol modellerinin olmamasıdır. Araştırma sonucunda elde edilen, çevresel destek ve engel düzeyinin mühendislik alanında erkek öğrenciler lehine farklılık gösterdiği sonucu da bunu destekler niteliktedir. Araştırmada, çevresel destek ve engel düzeyinin teknoloji ve matematik alanlarında cinsiyete göre farklılık göstermediği, fen ala- 
nında ise kız öğrenciler lehine farklılık gösterdiği belirlenmiştir. Bu sonucun, biyoloji, tıp, sağlık kariyerlerinde daha çok kadın rol model olmasından (National Center for Education Statistics, 2007) kaynaklanabileceği düşünülmektedir. Ayrıca bu sonucun, kadınların biyoloji, tıp ve sağlık bilimlerini seçme oranlarının, mühendislik, fizik ve bilişim alanlarını seçme oranlarına göre daha fazla olmasında (National Center for Education Statistics, 2007) etkili olduğu söylenebilir.

Araştırmada ikinci alt probleme ilişkin olarak öğrencilerin STEM kariyerlerine ilişkin kişisel amaç ve sonuç beklentilerinin cinsiyete göre farklılık göstermediği bulgusuna ulaşılmıştır. Son alt problemde ise öğrencilerin STEM alanlarındaki kariyerlere ilişkin kişisel amaç ve sonuç beklentilerinin, fen ve matematik alanlarında kız öğrenciler lehine, teknoloji ve mühendislik alanlarında erkek öğrenciler lehine anlamlı farklılık gösterdiği belirlenmiştir. Bu bulgunun, kız ve erkeklerin çoğunlukla seçtikleri STEM alanlarının da farklı olmasından kaynaklandığı düşünülmektedir. Nitekim yapılan çalışmalarda müsbet ve doğal bilimleri kadınların, mühendislik, üretim ve yapı alanlarını ise erkeklerin daha fazla seçtiği belirtilmektedir (Korkut-Owen vd., 2014; Sadler vd., 2012).

Araştırmada öğrencilerin SBKK faktörlerinden olan ilgi düzeylerinin, fen ve matematik alanlarında cinsiyete göre farkl1lık göstermezken teknoloji ve mühendislik alanlarında erkek öğrenciler lehine anlamlı farklılık gösterdiği sonucuna ulaşılmıştır. Bu bulgu, birinci alt probleme ilişkin olarak elde edilen, STEM kariyer ilgisinin fen ve matematik alanlarında kız öğrenciler lehine olumlu olduğu bulgusu ile örtüşmemektedir. Kişisel amaç ve sonuç beklentilerinin, fen ve matematik alanlarında, öz-yeterlik düzeyinin ise matematik alanında kız öğrenciler lehine olumlu olmasından dolayı STEM kariyer ilgisinin fen ve matematik alanlarında kız öğrenciler lehine farklılaştığı ifade edilebilir. Sonuç olarak STEM kariyer ilgisinin şekillenmesinde öz-yeterlik, kişisel amaç ve sonuç beklentileri faktörlerinin daha çok belirleyici olduğu söylenebilir. Bunu destekler nitelikte SBKK'na göre kariyer ilgisinin, temel olarak öz-yeterlik inançları ve sonuç beklentileri tarafından düzenlendiği; bireylerin kendilerini kişisel olarak yeterli bulduklarında ve olumlu sonuç beklediklerinde bir konuya ilişkin ilgilerinin sürdüğü belirtilmektedir (Lent vd., 1994). Araştırmada öğrencilerin kişisel eğilim düzeyinin cinsiyete göre teknoloji, mühendislik 
ve matematik alanlarında farklılık göstermezken fen alanında kız öğrenciler lehine anlamlı farklılık gösterdiği tespit edilmiştir. Sonuç olarak kız öğrencilerin teknoloji ve mühendislik alanlarındaki kişisel eğilimlerinin erken yaşlarda belirlenerek uygun rehberlik yapılması ile bu alanlara yönelik öz-yeterlik, kişisel amaç ve sonuç beklentilerinin de olumlu yönde geliştirilebileceği düşünülmektedir.

\section{Sonuç ve Öneriler}

Bu araştırmada SBKK açısından, ortaokul öğrencilerinin STEM kariyer ilgilerine cinsiyetin etkisinin belirlenmesi amaçlanmıştır. Araştırma sonucunda erkek öğrencilerin STEM kariyerlerine yönelik öz-yeterliklerinin ve ilgilerinin, kız öğrencilere göre daha olumlu olduğu sonucuna ulaşılmıştır. Bu sonucun nedeni, SBKK çerçevesinde araştırıldığında ise kız öğrencilerin teknoloji ve mühendislik alanlarına ilişkin öz-yeterlik, kişisel amaç ve sonuç beklentilerinin, erkek öğrencilere göre daha düşük olduğu bulgusuna ulaşılmıştır. SBKK'na göre bireylerin kariyer ilgileri, temel olarak öz-yeterlik inançları ve sonuç beklentileri tarafından düzenlenmektedir. (Lent vd., 1994). Sonuç olarak kız öğrencilerin teknoloji ve mühendislik alanlarına ilişkin öz-yeterlik, kişisel amaç ve sonuç beklentilerinin olumlu yönde gelişimi için ortaokul yıllarından itibaren bu alanlardaki kariyerlere ilişkin mesleki rehberlik sağlanması önerilmektedir.

Araştırmada elde edilen mühendislik alanındaki çevresel destek ve engel düzeyinin erkek öğrenciler lehine farklılık göstermesi sonucu, Türkiye'de mühendisliğin erkek egemen meslek olması ve bu kariyere sahip kadın rol modellerin yeterli olmaması ile açıklanabilir. Araştırmalarda ailesinde STEM alanlarında mesleğe sahip bireyler olanların, STEM kariyerlerini seçme ihtimallerinin daha fazla olduğu (Moakler ve Kim, 2014; Oware, Capobianco ve Diefes-Dux, 2007), kadın rol modellerin danışmanlığında gerçekleştirilen yaz kampı aktivitelerine katılan ortaokul kız öğrencilerinin, yükseköğretimde STEM kariyerlerine daha fazla ilgi duydukları (Dubetz ve Wilson, 2013) belirtilmektedir. Bu bağlamda özellikle kız öğrencilerin, okul dışı öğrenme ortamları ya da yaz kamplarında mühendislik alanındaki kadın rol modeller ile bir araya gelebilecekleri STEM eğitimine yönelik programlar düzenlenebilir. Örneğin ülkemizde 2015- 
2017 yılları arasında Koç Holding tarafından "Ülkem için Toplumsal Cinsiyet Eşitliğini Destekliyorum" projesi kapsamında Uçan Süpürge ve Milli Eğitim Bakanlığı işbirliği ile "Bal Arıları Mühendis Oluyor" adlı sosyal sorumluluk projesi gerçekleştirilmiştir. Projede gönüllü Ford Otosan mühendisleri de rol model olarak mühendislik mesleğini, çalışma koşullarını ve kendi tecrübelerini öğrencilere ve ailelerine aktarmıştır (BAMO, 2018). Ortaokul öğrencileri için benzer projeler düzenlenerek kariyer seçiminde toplumsal cinsiyet kalıplarından kaynaklanan önyargıların yıkılması ve daha fazla kız öğrencinin kariyer olarak mühendisliği seçmesi sağlanabilir.

Araştırmada kız öğrencilerin fen ve matematik alanlarına yönelik kariyer ilgilerinin, erkeklere göre daha olumlu olduğu sonucuna ulaşılmıştır. Kız öğrencilerin mühendislik ve teknoloji alanlarına yönelik ilgilerinin de geliştirilmesi için mühendisliğin fen, matematik ve teknoloji ile olan bağlantısı kavratılmalıdır. Bunu gerçekleştirmenin yolu ise ülkemizde de son yıllarda üzerinde çokça durulan STEM eğitimidir. Araştırmalarda STEM eğitiminin, öğrencilerin STEM kariyer ilgilerini olumlu yönde etkilediği (Christensen ve Knezek, 2017; Wyss vd., 2012) belirtilmektedir.

$\mathrm{Bu}$ araştırma, Ege bölgesinin kırsal bir ilçesinde öğrenimlerine devam eden 400 ortaokul öğrencisi ile sinırlıdır. Araştırmacılar, farklı bölgelerdeki, farklı öğretim kademelerindeki öğrencilerin STEM kariyer ilgilerine cinsiyet veya cinsiyet dışındaki diğer değişkenlerin etkisini belirlemeye yönelik araştırmalar yapabilirler. SBKK açısından STEM kariyer ilgisini belirlemeyi amaçlayan farklı ölçme araçları geliştirilebilir ve kullanılabilir. Öğrencilerin STEM kariyerlerine ilişkin öz-yeterlik, ilgi, kişisel amaç ve sonuç beklentilerini daha ayrıntılı değerlendirmek amacı ile nitel araştırmalar yapılabilir. 


\title{
EXTENDED ABSTRACT
}

\section{The Impact of Gender on STEM Career Interest in Terms of the Social Cognitive Career Theory}

\author{
Ayşegül Ergün \\ Manisa Celal Bayar University
}

In 21st century, very speedy developments are taking place in information and communication technologies with globalization. These developments have resulted in the economies of countries to be more based on information. The need of countries which desire to have a global power of competition in economic terms for individuals who can develop new technologies has increased as well. In this regard, the primary goal of countries has become educating individuals who make careers in the areas of science, technology, engineering and mathematics (STEM). In many European countries, although the interest in STEM education has increased, a decrease has taken place in the number of students who choose physical sciences, engineering and mathematics in university education. In Turkey, it is reported that the rate of the first one thousand students who were placed in universities in STEM areas from 2000 to 2014 has decreased as well. According to the report of Turkish Industrialists' and Businessmen's Association (TUSIAD), it is foreseen that about $31 \%$ of the demand for STEM labor force will not be met in 2016-2023.

The Social Cognitive Career Theory (SCCT) is based on the idea that cognitive factors are effective in the process of choosing careers and that individuals have the capacity to guide their own career processes. SCCT underlines that the relationship between individual, environmental and behavioral variables in terms of the individual's career selection is effective. These variables are expressed as self-efficacy beliefs, expectations related to results, personal goals, interests, environmental supports and barriers and personal tendency. It is stated that STEM career interest is the main component of SCCT and it provides a good point of view in terms of individuals' preferring STEM careers. In the literature, it has been seen that studies which deal with STEM career interest in relation to SCCT mostly involve high-school and university students. Although there are 
studies which involve middle-school students as well, it is noteworthy that these are less in number compared to studies dealing with highschool and university levels.

Since middle-school years are critical in the sense that students' career preference is shaped during this period, these years are stated to have a powerful effect on education about careers received in the later periods. Therefore, it is important to determine students' STEM career interests during their middle-school years. In general, it has been seen in studies that male students' STEM career interest is more positive compared to female students and that in particular careers in the areas of engineering and technology are chosen more by male students. Since the number of studies which deal with STEM career interest in the middle-school level in terms of SCCT are lower in number compared to the high-school and university levels, it has been aimed in this study at determining the effect of gender on the STEM career interest of middle-school students in terms of SCCT. The problem sentence of the study has been determined as: "Does the STEM career interest of middle-school students in relation to SCCT display significant differences in terms of gender?" In this respect, the answers to the following sub-problems have been sought:

1. Does the students' STEM career interest display a significant difference in terms of gender?

2. Does the students' STEM career interest display a significant difference in terms of gender in relation to the SCCT factors?

3. Does the students' career interest related to each of the STEM areas display a significant difference in terms of gender in SCCT factors?

The sample of the study consists of 400 students (218 female and 182 male students) who are receiving education at public middle-school in a city in the Aegean region in Turkey. Data of the study in which general survey model has been used have been collected through the STEM career interest survey.

As a result of the study, it has been determined in relation to the first sub-problem that the STEM career interests of the male students are more positive compared to the female students. It has been seen that the level of interest displays a significant difference in the favor of female students in the areas of science and mathematics and in the favor of the male students in the areas of technology and engineering. It can be stated that the 
reason why the STEM career interest of the female students is negative compared to the male students is that the female students' career interests in the areas of engineering and technology is lower compared to the male students. Similarly, it is stated in other studies that STEM career inequality against female students is seen more in engineering rather than science and that female students' attitudes towards engineering and technology are more negative in all educational levels compared to male students.

In relation to the second sub-problem, it has been determined that the self-efficacy and interest of the male students in terms of their STEM careers is higher compared to the female students. In relation to the last subproblem, it has been determined that self-efficacy levels do not display a significant difference in the area of science in terms of gender and that there is a difference in the favor of the male students in the areas of technology and engineering and in the favor of the female students in the area of mathematics. In the study, it has been determined that environmental support and barriers level does not display a difference in the areas of technology and mathematics in terms of gender and that there is a difference in the favor of the male students in the area of engineering and in the favor of the female students in the area of science. Since engineering is regarded as a male dominated career in Turkey and the role models in this area are mostly males, it can be stated that the self-efficacy of the female students is lower in the area of engineering. The female students' environmental support and barriers level being higher in the area of science can be explained by the fact that women have a higher rate of choosing the areas of biology, medicine and health sciences compared to the areas of engineering, physics and informatics and having more role models in the careers of biology, medicine and health. It has been determined that personal goals and expectations related to results in relation to STEM careers display a significant difference in the favor of the female students in the areas of science and mathematics and in the favor of the male students in the areas of technology and engineering. It is considered that this finding is due to STEM areas chosen mostly by the female and male students being different. In other studies, it is stated that positive and natural sciences are chosen more by women and areas of engineering, production and construction are chosen more by men. As a result of the study, it has been determined that self-efficacy, personal goals and expectations related to 
the results have a more determining effect in the shaping of STEM career interest.

In the light of the findings obtained in the study, it is suggested to provide sufficient occupational guidance starting from the middle-school years for the positive development of the female students' career interests related to technology and engineering. Programs about STEM education, in which the female students can meet female role models in the area of engineering in learning environments outside of schools or in summer camps can be organized. It is suggested to use the STEM education approach in an effective manner to make it possible for the students to understand the relationship of engineering with mathematics and technology and to develop their STEM career interest in a positive manner.

\section{Kaynakça / References}

Akgündüz, D. (2016). A research about the placement of the top thousand students in STEM fields in Turkey between 2000 and 2014. Eurasia Journal of Mathematics, Science \& Technology Education, 12(5), 1365-1377.

Bal Arıları Mühendis Oluyor (BAMO) (2018). RMK Marine. 17 Aralık 2018 tarihinde http://www.rmkmarine.com.tr/bal-arilari-muhendis-oluyorprojesi.html adresinden erişilmiştir.

Bandura, A. (1986). Social foundations of thought and action: A social cognitive theory. Englewood Cliffs, NJ : Prentice - Hall .

Betz, N. E., ve Hackett, G. (1983). The relationship of mathematics self-efficacy expectations to the selection of science-based college majors. Journal of Vocational Behavior, 23, 329-345.

Betz, N. E. (2007). Career self-efficacy: Exemplary recent research and emerging directions. Journal of Career Assessment, 15(4), 403-422.

Brotman, J. S., ve Moore, F. M. (2008). Girls and science: A review of four themes in the science education literature. Journal of Research in Science Teaching, 45(9), 971-1002. doi:10.1002/tea.20241.

Büyüköztürk, Ş. (2017). Veri analizi el kitabı (23. Baskı). Ankara: Pegem Akademi Yayıncilik.

Ceci, S. J., ve Williams, W. M. (2010). Sex differences in math-intensive fields. Current Directions in Psychological Science, 19(5), 275-279. 
Christensen, R., ve Knezek, G. (2017). Relationship of middle school student STEM interest to career intent. Journal of Education in Science, Environment and Health (JESEH), 3(1), 1-13.

Dubetz, T., ve Wilson, J.A. (2013). Girls in engineering, mathematics and science, GEMS: A science outreach program for middle-school female students. Journal of STEM Education, 14(3), 41-47.

Ferry, T. R., Fouad, N. A., ve Smith, P. L. (2000). The role of family context in a social cognitive model for career-related choice behavior: A math and science perspective. Journal of Vocational Behavior, 57, 348 -364.

Fouad, N. A., ve Smith, P. L. (1996). A test of a social cognitive model for middle school students: Math and science. Journal of Counseling Psychology, 43, 338-346.

Hackett, G. (1985). Role of mathematics self-efficacy in the choice of mathrelated majors of college women and men: A path analysis. Journal of Counseling Psychology, 32, 47-56.

Karasar, N. (2009). Bilimsel araştırma yöntemi: Kavramlar, ilkeler, teknikler (4. bs.). Ankara: Nobel Yayın.

Kier, M. W., Blanchard, M. R., Osborne, J. W., ve Albert, J. L. (2014). The development of the STEM career interest survey (STEM-CIS). Research in Science Education, 44(3), 461-481.

Knezek, G., Christensen, R., ve Tyler-Wood, T. (2011). Contrasting perceptions of STEM content and careers. Contemporary Issues in Technology and Teacher Education, 11(1), 92-117.

Knight, M. ve Cunningham, C. M. (2004). Draw an engineer test (DAET): Development of a tool to investigate students' ideas about engineers and engineering. In Proceedings of the 2004 ASEE annual conference and exposition, Salt Lake City, Utah.

Korkut-Owen, F., Kelecioglu, H., ve Owen, D. W. (2014). A decade of change gender trends in university enrollment: Implications for career counseling. International Journal of Human Sciences, 11(1), 794-813.

Koyunlu Unlu, Z., Dokme, I., ve Unlu, V. (2016). Adaptation of the science, technology, engineering, and mathematics career interest survey (STEM-CIS) into Turkish. Eurasian Journal of Educational Research, 63, 21-36, http://dx.doi.org/ 10.14689/ejer.2016.63.2

Lent, R. W., Brown, S. D., ve Hackett, G. (1994). Toward a unifying social cognitive theory of career and academic interest, choice, and performance. Journal of Vocational Behavior, 45(1), 79-122. 
Lent, R. W., Brown, S. D., Brenner, B., Chopra, S. B., Davis, T., Talleyrand, R., ve Suthakaran, V. (2001). The role of contextual supports and barriers in the choice of math/science educational options: A test of social cognitive hypotheses. Journal of Counseling Psychology, 48, 474 - 483.

Lent, R. W., Brown, S. D., Schmidt, J., Brenner, B., Lyons, H., ve Treistman, D. (2003). Relations of contextual supports and barriers to choice behavior in engineering majors: Test of alternative social cognitive models. Journal of Counseling Psychology, 50, 458 - 465.

Lent, R.W., Brown, S.D., Sheu, H.B., Schmidt, J., Brenner, B.R., Gloster, C.S., Wilkins, G., Schmidt, L.C., Lyons, H. and Treistman, D. (2005). Social cognitive predictors of academic interests and goals in engineering: Utility for women and students at historically black universities. Journal of Counseling Psychology, 52(1), 84.

Lent, R. W., ve Brown, S. D. (2006). Integrating person and situation perspectives on work satisfaction: A social-cognitive view. Journal of Vocational Behavior, 69(2), 236-247.

Lent, R. W., Sheu, H., Gloster, C. S., ve Wilkins, G. (2010). Longitudinal test of the social cognitive model of choice in engineering students at historically Black universities. Journal of Vocational Behavior, 76, 387-394. DOI:10.1016/j.jvb.2009.09.002.

Lopez, F. G., Lent, R. W., Brown, S. D., ve Gore, P. A. (1997). Role of socialcognitive expectations in high school students' mathematics related interest and performance. Journal of Counseling Psychology, 44, $44-52$.

Milli Eğitim Bakanlığı. (2006), İlköğretim fen ve teknoloji dersi (6, 7 ve 8. Sinıflar) öğretim programı. Ankara: Talim ve Terbiye Kurulu Başkanlığı.

Milli Eğitim Bakanlığı. (2016). STEM eğitimi raporu. 05 Kasım 2018 tarihinde http://yegitek.meb.gov.tr/STEM Egitimi Raporu.pdf adresinden erişilmiştir.

Milli Eğitim Bakanlığı. (2017). Fen bilimleri dersi öğretim programı (İlkokul ve Ortaokul 3, 4, 5, 6, 7 ve 8. Sinfflar). 11 Ekim 2017 tarihinde http://mufredat.meb.gov.tr adresiden erişilmiştir.

Milli Eğitim Bakanlığı. (2018). Fen bilimleri dersi öğretim programı (İlkokul ve Ortaokul 3, 4, 5, 6, 7 ve 8. Sinflar). 05 Ekim 2018 tarihinde http://mufredat.meb.gov.tr/ProgramDetay.aspx?PID=325 adresinden erişiilmiştir.

Moakler, M. ve Kim, M. M. (2014). College major choice in STEM: Revisiting confidence and demographic factors. Career Development Quarterly, 62, 128-143. 
National Center for Education Statistics (2007). Encouraging girls in math and science: IES practice guide. US Department of Education. 22 Kasim 2018 tarihinde $\quad$ https://ies.ed.gov/ncee/wwc/Docs/PracticeGuide/20072003.pdf adresinden erişilmiştir.

Navarro, R. L., Flores, L. Y., ve Worthington, R. L. (2007). Mexican American middle school students' goal intentions in mathematics and science: A test of social cognitive career theory. Journal of Counseling Psycho$\log y, 54(3), 320$.

Niles, G.N., ve Harris-Bowlsbey J. (2013). 21.yüzyılda kariyer gelişimi müdahaleleri (4. Basım) (Çev. F. K. Owen). Ankara: Nobel Yayınevi.

O’Brien, V., Martinez-Pons, M., \& Kopala, M. (1999). Mathematics selfefficacy, ethnic identity, gender and career interests related to mathematics and science. Journal of Educational Research, 92(4), 231-235.

Organisation for Economic Cooperation and Development. (2017). Türkiye ülke notları bir bakışta eğitim 2017: OECD göstergeleri. 29 Ekim 2018 tarihindehttp://www.oecd.org/education/skills-beyondschool/EAG2017CN-Turkey-Turkish.pdf adresinden erișilmiștir.

Osborne, J., ve Dillon, J. (2008). Science education in Europe: Critical reflections. London: The Nuffield Foundation.

Oware, E., Capobianco, B. ve Diefes-Dux, H. (2007). Gifted students' perceptions of engineers? A study of students in a summer outreach program. Paper presented at 2007 Annual Conference \& Exposition, Honolulu, Hawaii.

Owen, F. K., ve Çapan, B. E. (2017). Ortaöğretim öğrencilerinin fen teknoloji matematik ve mühendislik alanlarını seçmeyi düşünme nedenleri. Yaşadıkça Ĕ̆itim Dergisi, 31(2), 23-40.

Sadler, P. M., Sonnert, G., Hazari, Z., ve Tai, R. (2012). Stability and volatility of STEM career interest in high school: A gender study, Science Education, 96(3), 411-427. DOI: 10.1002/sce.21007.

Sauermann, H. (2005). Vocational choice: A decision making perspective. Journal of Vocational Behavior, 66, 273-303.

Su, R., Rounds, J., ve Armstrong, P. I. (2009). Men and things, women and people: A meta-analysis of sex differences in interests. Psychological Bulletin, 135(6), 859-884.

Turner, S. L., ve Lapan, R. T. (2005). Evaluation of an intervention to increase non-traditional career interests and career-related self-efficacy among middle-school adolescents. Journal of Vocational Behavior, 66, 516 -531. 
Türk Sanayicileri ve İş Adamları Derneği. (2017). 2023'e doğru Türkiye'de STEM gereksinimi.05 Kasım 2018 tarihinde https://www.tusiadstem.org/images/raporlar/2017/STEM-Raporu-V7.pdf adresinden erişilmiştir.

Unfried, A., Faber, M., ve Wiebe, E. (2014). Gender and student attitudes toward STEM. Presented at the AERA Annual Meeting, Philadelphia, PA.

Wang, M-T. ve Degol, J. (2013). Motivational pathways to STEM career choices: Using expectancy-value perspective to understand individual and gender differences in STEM fields. Developmental Review, 33, 304340.

Wang, X. (2013). Why students choose STEM majors: Motivation, high school learning, and postsecondary context of support. American Educational Research Journal, 50, 1081-1121. DOI:10.3102/0002831213488622

Wells, B., Sanchez, A., ve Attridge, J., (2007). Modeling student interest in science, technology, engineering and mathematics. IEEE Summit. "Meeting the Growing Demand for Engineers and their Educators," Munich, Germany.

Wyss, V. L., Heulskamp, D. ve Siebert, C. J., (2012). Increasing middle school student interest in STEM careers with videos of scientists. International Journal of Environmental Science Education, 7(4), 501-522.

Yerdelen, S., Kahraman, N., ve Taş, Y. (2016). Low socioeconomic status students' STEM career interest in relation to gender, grade level, and STEM attitude. Journal of Turkish Science Education. 13(Special Issue), 59-74.

Yıldırım, A., ve Şimşek, H. (2016). Sosyal bilimlerde nitel araştırma yöntemleri (10. Bs.). Ankara, Seçkin Yayıncılık.

\section{Kaynakça Bilgisi / Citation Information}

Ergün, A. (2019). Sosyal bilişsel kariyer kuramı açısından STEM kariyer ilgisine cinsiyetin etkisi. OPUS-Uluslararası Toplum Araştırmaları Dergisi, 14(20), 1284-1311. DOI: 10.26466/opus.603981 